\title{
Handling of pastoral misconduct and discipline: Evidence from the Apostolic Faith Mission in Zimbabwe church
}

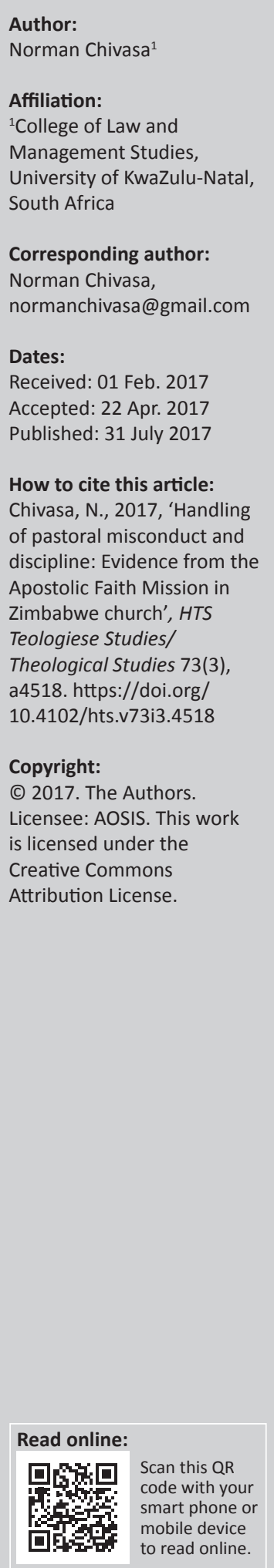

Misconduct has permeated almost every community across the globe and Christian churches have not been spared either. The two basic questions that the current study addresses were what are some of the reported behaviours of male pastors that constitute misconduct in the Apostolic Faith Mission (AFM) in Zimbabwe church?; and is there any policy framework in the AFM in Zimbabwe designed to repair distressed relationships between offending pastors and the church? Results showed that in the AFM in Zimbabwe, pastoral misconduct is seen as a negative force that militates against sustaining harmony in the church. As such, whenever a male pastor commits an act of misconduct, disciplinary action is taken against him. It was also found that constructive dialogue to address misconduct is still a blind spot in the church under review. And because there is no policy framework to amend distressed relationships after administering discipline, social interactions between offending pastors and the church remain antagonistic. In view of the identified problem, this study proposed that the AFM in Zimbabwe might need to embrace a peace building framework because it has the propensity to repair broken relationships and to build friendships, social networks and trust between people. This framework can be instrumental in repairing distressed relations between offending pastors and the church at large. The strength of peace building lies in the values of brotherly love, forgiveness, reconciliation and relationship building, which are compatible with Christianity.

\section{Introduction}

It has long been recognised that the Apostolic Faith Mission (AFM) in Zimbabwe church is the mother of Pentecostalism in Zimbabwe (Hwata 2005:27; Machingura 2011:18; Nhumburudzi 2016:31; Togarasei 2016:2). In 2015, the AFM in Zimbabwe celebrated 100 years of active ministry across Zimbabwe (Madziyire \& Risinamhodzi 2015:105; Murefu 2015:1) and the denomination claims to have more than two million members (http://www.pindula.co.zw) in a population of 13 million people (Machingura 2011:17). The current study attempts to address two basic questions; What are some of the typical behaviours of pastors that exacerbate discordance? Is there any policy framework in the AFM in Zimbabwe designed to repair distressed relationships between pastors in question and the church? The motivation to conduct this study was sparked by the realisation that empirical studies on pastoral misconduct by male pastors in the church under review remains limited (Chivasa 2012:3-6; Chivasa \& Machingura in press), and therefore, this study seeks to add a voice rather than being a stand-alone research project.

The current study takes place in the context of various research projects on misconduct involving Christian pastors. The majority of these previous studies have focused only on adultery/extramarital affairs committed by male pastors (Barna Group 2016; Cecil 1997; Johnson 2015; King 1988; Roys 2015; Smietana 2016). This study reports on inappropriate sexual behaviours, embezzlement of church funds, confiscation of church property and cases of rape, among other cases of misconduct, which involve male pastors in the AFM in Zimbabwe church. For the purposes of this study, these behaviours constitute pastoral misconduct and they warrant academic interrogation. This study is not concerned with the origins and the actual date when pastors started committing misconduct in the AFM in Zimbabwe, but offers a bird's-eye view of pastors' behaviours for a better understanding of how these acts of misconduct generate discordance that affects the church.

However, to avoid generalisation of pastoral misconduct in the AFM in Zimbabwe church as a whole, Masvingo province was purposively selected for this study. Masvingo province met the study's inclusion criteria for provinces with comparative advantages relating to hosting pastors' 
national seminars and conferences more than other provinces did in a year. As mentioned already, this study reports the behaviour of male pastors that exacerbate discordance in the AFM in Zimbabwe. Such behaviours have direct negative implications for the reputation of the AFM as the mother of Pentecostalism in Zimbabwe and intensify people's negative attitudes towards men of the cloth.

Since male pastors are the primary perpetrators of anti-social behaviours, this study was intended to add to the limited number of studies on the interface between reported behaviours of male pastors and discordance in Christian denominations. The first part of this paper clarifies key terms, which serve as forerunners to this study. The second part, reviews how misconduct is understood, categorized and handled in the AFM in Zimbabwe. The third part describes data collection methods. The fourth section presents and discusses research results and findings. The fifth section recommends the framework that the church under review might need to consider to help repair distressed relations after taking disciplinary action.

\section{Clarification of key terms}

\section{Church}

The term church comes from a Greek word ekklesia, which means an assembly or congregation and it has come to mean a group of people who profess their faith in Jesus Christ. In that sense, church is not a building but a community of believers who share common norms and values (Taylor 2004:1). The Constitution and Regulations of the AFM in Zimbabwe describe a church as a specific place where a group of people amounting to a minimum of 50 adults are organised under the supervision of a committee of elders under the leadership of a pastor (Constitution and Regulations of the AFM in Zimbabwe, Chapters 3.1.1 \& 17.6.1.).

\section{Disciplinary measures}

The Dictionary of church terms defines discipline as a penalty that is imposed by spiritual leaders on a member of a church who commits a misconduct to help him or her restore his or her relationship with fellow Christians and God (Malaty 1992:39). This definition puts the popular 'Robert's rules of order into perspective'. In the book, Robert's rules of order, disciplinary measures are deliberate actions taken by an organisation to put a member of the group under censure, suspension or expulsion for allegedly committing an act of misconduct (Robert et al. 2011:646). In Christian churches, disciplinary measures are taken when one member of the church (a pastor in the case of this study) has committed what the church perceives as a threat to its assumption of one voice. In the AFM in Zimbabwe, the term discipline is used interchangeably with censorship. In Chapter 16.4.2 of the Constitution and Regulations, 'a person under censure [discipline] may not hold any office in the church'. A period of censure in the church under review varies from 3 to 12 months depending on the seriousness of the misconduct.

\section{Misconduct}

To avoid ambiguities associated with the wide usage of the term misconduct in the corporate world, this study relied on the dictionary definition and conceptions of the church under review. The Special Education Dictionary (2003) defines misconduct as an unacceptable or improper behaviour motivated by premeditated, purposeful or obstinate indifference to the consequences of one's acts. For the purposes of this study, an act of misconduct entails discordance in which the church deliberately or unwittingly becomes divided over the behaviour of a fellow Christian(s). Smietana (2016) observed three common discordance faced by Christian churches when a pastor has committed a misconduct. Firstly, should a pastor alleged to have committed misconduct step down? The second question is, should the congregation be informed about the allegations levelled against the pastor while investigations are underway? Thirdly, should a pastor who has committed adultery be reinstated back into ministry or not? It is interesting to note that there is no consensus among Christian churches on the best approach to handling pastoral misconduct and the AFM in Zimbabwe has not been spared either.

\section{Pastoral care}

A pastor is a spiritual leader whose primary responsibility is to provide pastoral care. Rowdon (2009:227) defines pastoral care as a role that is associated with teaching, preaching, counselling or attending to the other specific needs of individual members of a particular church. Moyo (2015:3) views pastoral care as actions motivated by love, kindness, mercy directed to the sick and afflicted members of the church and community at large. Within this framework, when a pastor commits an act of misconduct, members of the church or people who might want to convert to Christianity may get frustrated to know that pastors to whom they seek for pastoral care are involved in such vices (Chivasa 2012:2).

\section{Perceptions of misconduct in the AFM in Zimbabwe}

A critical reading of the Constitution and Regulations and Document of the AFM in Zimbabwe reveals that the church under review undoubtedly prefers harmony than misconduct. The church under review's understanding of misconduct is guided by definitions outlined in Table 1 . In principle, there are three primary terms associated with misconduct; the first is an accusation, which occurs when a pastor violates the dictates of the constitution. Alternatively, an accusation can be an allegation levelled against a pastor by fellow church members. The second is an offence, which refers to an act committed by a pastor or church member, which attracts disciplinary action by the church authorities. The third and last is a complaint denoting grievance/objection against an Overseer, pastor or church member (Constitution and Regulations of the AFM in Zimbabwe, Chapter 16; Policy Document, Chapter 14). 
TABLE 1: Categories of serious misconduct.

\begin{tabular}{|c|c|}
\hline Serious acts of misconduct & Definition \\
\hline Adultery and fornication & $\begin{array}{l}\text { Committing sexual activities outside the realm of } \\
\text { marriage }\end{array}$ \\
\hline Rape and sexual assault & $\begin{array}{l}\text { Forcing oneself upon another without consent of the } \\
\text { other }\end{array}$ \\
\hline Divorce & $\begin{array}{l}\text { Separating oneself from his or her legal husband or } \\
\text { spouse }\end{array}$ \\
\hline Marital disharmony & $\begin{array}{l}\text { Where a couple engages in public fighting or public } \\
\text { discord }\end{array}$ \\
\hline Abortion and murder & Taking the life of another including that of the foetus \\
\hline Robbery & Taking away the property of another unlawfully \\
\hline Theft and fraud & $\begin{array}{l}\text { Removing money or property by trickery, fraudulent } \\
\text { means }\end{array}$ \\
\hline Negligence & Not taking reasonable care or acts of omission \\
\hline Misuse of property & Using church property for personal gain or private use \\
\hline Abusive language & Impairing the dignity of others and provoking violence \\
\hline Disorderly behaviour & $\begin{array}{l}\text { Unruly, endangering the safety of others and church } \\
\text { worship }\end{array}$ \\
\hline Assault & $\begin{array}{l}\text { Intimidation, physical assaults and being violent to } \\
\text { others }\end{array}$ \\
\hline Fighting & Exchanging blows whether after provocation or not \\
\hline
\end{tabular}

Source: AFM in Zimbabwe Policy Document, Chapter 4.5

All the three terms associated with misconduct are important and have parallels with secular conceptions of offences in the Criminal Law (Codification and Reform) Act (Chapter 9:23). This is so because acts of misconduct involve inappropriate behaviours such as fraud, robbery, misuse of property, or assault (to mention only a few), are alleged to have been committed, any inquiry into such allegations is rooted in the alleged acts violating the dictates of the church constitution. The point is always, when pastors and church members talk about misconduct, it is usually filtered through the framework of an accusation, offence or complaint (Constitution and Regulations of the AFM in Zimbabwe, Chapter 16; Policy Document, Chapter 14). This conception of misconduct in the AFM in Zimbabwe affects the way in which it is addressed whenever a pastor commits an act of misconduct. Instead of embracing dialogue to remedy the perceived misconduct, the process turns out adversarial. It is the Constitution and Regulations of the church under review that influences how pastoral misconduct is handled.

\section{Categories of misconduct in the Apostolic Faith Mission in Zimbabwe}

Any considerations of misconduct within the context of the church under review must take the Constitution and Regulations and Policy Document of this church seriously. As part of its primary objectives, the AFM in Zimbabwe is highly committed to upholding the integrity of the church through the administration of discipline against pastors and church members who commit acts of misconduct. The church classifies misconduct in two major categories, namely serious misconduct and not-so-serious misconduct. Serious misconduct is characterised by specific acts shown in Table 1 .

As outlined in the Constitution and Regulations, any pastor who commits serious misconduct is subjected to disciplinary measures, whereas a pastor who commits a not-so-serious misconduct is subjected to sanctions that include counselling, confession and restitution (Chapter $16.2 \& 16.3$ ). In contrast to serious misconduct, not-so-serious misconduct is associated with absenteeism from church meetings, unauthorised use of church vehicle, abuse of office, breach of confidentiality, loss or damage of church property through negligence, among others (Policy Document, Chapter 14.5.2). As shown in Table 1, acts of serious misconduct are classified as offences in the Policy Document of the AFM in Zimbabwe. These offences attract disciplinary measures. Accordingly, a significant portion of the AFM in Zimbabwe's concept of misconduct involves offences by pastors or church members. Indeed, if one word were to be used to describe the perceptions of misconduct in the AFM in Zimbabwe, negative would be an appropriate one. This is so because serious misconduct is seen as an offence that militates against harmony sustenance in the church (Chivasa 2012:9). This association of misconduct with offences exhibits some parallels with the Criminal Law (Codification and Reform) Act [Chapter 9:23] in Zimbabwe, which defines offence as crime or misconduct punishable by law. In the church under review, serious misconduct is punishable by disciplinary measures.

Nevertheless, in order to understand why misconduct is classified as an offence in the AFM in Zimbabwe, these perceptions of misconduct should be situated within particular the circumstances that the church is faced with. These circumstances include the moral failures of male pastors in the AFM in Zimbabwe. Taken on their own terms, the AFM in Zimbabwe's experience of pastoral misconduct are thus intertwined with moral failures of some pastors and the desire to promote virtuous Christian living and these must be considered together.

To promote virtuous Christian living, taking disciplinary measures against pastoral misconduct seems to have been the AFM's official policy over the years and even until today (Constitution and Regulations, Chapter16; Policy Document, Chapter 14.7). In other words, the church under review continues to embrace disciplinary measures in spite of the negative impact that disciplinary action has on the relationships between offending pastors and the church. Disciplinary action is done despite several calls for dealing with misconduct that emphasise dialogue between discordant parties (Chivasa 2012:70). The primary mechanism for handling misconduct is through arbitration. Arbitration involves a third party making a decision regarding a matter in question (Tillett 1999:97). In many cases in the process of administering disciplinary action against the offender, adversarial relations between offending pastors and the church become a characteristic feature (Chivasa 2012:34). As Chivasa and Machingura (in press) observed, adversaries fight every now and then and antagonistic relations are of no benefit to the church because its primary objective is to model love, tolerance, peace, forgiveness and mutual understanding among other values and not to fan divisions and hatred.

\section{Procedures for handling pastoral misconduct and discipline in the Apostolic Faith Mission in Zimbabwe}

A procedure is a set of actions or systematic steps taken to address an act of misconduct (Chivasa 2012:32). The AFM in 
Zimbabwe has as code of conduct and grievance handling procedure (CCGHP), which provides steps for handling acts of misconduct in the church (Chapter 14). The CCGHP supplements Chapter 16 of the Constitution and Regulations, which deals specifically with issues of misconduct. In Chapter 16, the procedure for handling pastoral misconduct is that allegations against a pastor should be put in writing and signed by two witnesses and submitted to the immediate supervisor of the pastor in question. Upon receiving allegations, the immediate supervisor will appoint two men to investigate the matter and report back. Findings on allegations are discussed in a provincial council meeting, and if the pastor is found guilty, the matter is referred to the Apostolic Council for ruling. The Constitution \& Regulations sums it up as follows:

- Any complaint against a Full Time Worker (pastor) must be submitted in writing and signed by the complainant and two or three witnesses.

- The accusation must be submitted to the council under whose immediate authority the Full Time Worker falls.

- The accused must be notified of the charge against him and the date of the hearing.

- The Apostolic Council shall appoint a court of at least four members to hear the case and pronounce judgment.

- If the accused is found guilty, (the Apostolic Council) may resolve to seriously admonish the transgressor and, if advisable insist on confession and restitution. They may decide to place the guilty party under censure ${ }^{1}$ for a given period. (Chapter 16.4.1; 10.1.1 \& 16.15.1)

As the Constitution and Regulations seem to suggest, procedures for handling pastoral misconduct are bureaucratic in the church under review. This is so because the Apostolic Council, which is chaired by the president of the church, is also a primary arbitrator in deciding the outcome of misconduct that occurs at a local church. Somehow, this shows that participation of local structures (such as the local board of elders) in addressing pastoral misconduct is still a blind spot (Chivasa 2012:10). The local board of elders works on daily basis with the alleged pastor and members of the board are in some way well versed with the dynamics surrounding the pastor's misconduct because they are his church mates. Ironically, when a pastor commits an act of misconduct, the local board of elders only play the role of an accuser. This is so because the procedures of the church seem to shy away from the local board of elders participating in addressing pastoral misconduct, yet they are better informed as to the dynamics surrounding pastoral misconduct. In the church under review, the Apostolic Council, which is remotely located relative to the pastor's work place, is given the mandate by the Constitution and Regulations to decide upon the outcome of the misconduct. In that case then, constructive dialogue appears to lie almost outside the realm of the AFM in Zimbabwe's current approach to misconduct. In fact, the church under review appears to embrace the criminal model, which justifies that the offender must suffer for his actions (Chivasa \& Machingura in press). Even for pastors who have spent so much time (3-year theological training) at seminaries, their approach to misconduct, including the general tenor and mood of the AFM in Zimbabwe's reaction to misconduct, militates against relationship building.

Given that no further efforts are taken to mend relationships between the church and the offending pastor after disciplinary action, the need for a relationship-oriented policy framework in the AFM in Zimbabwe has been long overdue. Under these circumstances, a relationship-oriented framework is crucial, bearing in mind that Christianity is relationship oriented. As such, when an act of misconduct has occurred, the law of love should be the guiding principle in which case church members should be seen collaborating when a problem arises. Positive though it may sound, the relationshiporiented framework is not meant to create a perfect church but to help it become a church that handles pastoral misconduct in a way that builds trust and enhances relationships and friendships between people. It is, therefore, to be hoped that the relationship-oriented framework to be recommended in this study is likely to be practical and realistic and does not end as ideas in the air.

\section{Research methods}

This study was predominantly qualitative in that key informant interviews, insider participant observation and documentary review were instrumental in the research process. The researcher was a member of the provincial council for a period of 10 years, including the period, 2000 to 2009. Documents reviewed include the Constitution and Regulations, Policy Document of the AFM in Zimbabwe, and grey literature relating to pastoral misconduct in the church under review.

To enable informants to share their experiences of pastoral misconduct and discipline that exacerbate discordance in the AFM in Zimbabwe, key informant interviews proved helpful. The following open-ended interview guide was instrumental:

- Which are the most reported behaviours of pastors in this province?

- What happens to a pastor involved in any of the behaviours mentioned above?

- What would you recommend to repair distressed relationships between offending pastors and the church?

I made use of the purposive technique to select individuals I considered to be information-rich sources. By the time of this study, Masvingo provincial council consisted of 336 council members comprising the sitting Overseer, 23 pastors, 147 elders, 147 deacons from 21 local churches, 16 Overseers from the Apostolic Council and 2 former Overseers. Because the study was targeting Masvingo provincial council, which had predominantly male members, the purposive technique, proved helpful. However, in the process, I found myself switching between purposive and snowball sampling 
techniques, in which case I ended up giving some informants the prerogative to refer me to like-minded information-rich sources. Using existing networks, pastors, elders and deacons linked me up with other informants and I was able to access 30 members of the provincial council and two Overseers from other provinces who participated in the study before I reached saturation point. I proceeded with interviews with another 10 informants and stopped at 40 after realising that I was getting the same information I had collected before. To protect the integrity and identification of individuals, the titles pastor and Overseer are used in the report to avoid any direct linkages to specific behaviours reported in this study.

\section{Research results}

\section{Pastoral acts of misconduct and how they were handled}

Case 1: In 1990, the church elders levelled allegations of sexual immorality against a pastor. After investigations by the Provincial Committee, the matter was discussed in the provincial council meeting and a resolution was passed to suspend the pastor indefinitely.

Case 2: In 1994, church elders and some pastors levelled allegations of an extra-marital affair against a pastor to the Provincial Overseer. The Provincial Committee made investigations and passed a resolution to place the pastor under censure for one year pending reinstatement.

Case 3: In 1995, some elders and pastors levelled allegations of promiscuity against a Provincial Overseer. Following investigations, the Apostolic Council passed a resolution to depose the Overseer with a subsequent indefinite period of censure.

Case 4: The same year some church members levelled allegations of an extra-marital affair against a pastor. The Provincial Committee probed the matter but found no substantial evidence and the matter came to a standstill.

Case 5: In 1996, some elders in one congregation levelled allegations of an extra-marital affair against a pastor. A written report was forwarded to the Provincial Committee and the pastor denied the allegations. The Provincial Committee made a resolution to transfer the pastor to another congregation and the case came to a standstill.

Case 6: The same year some members of the church levelled allegations of confiscating church property against a pastor and before investigations were made, it appears the pastor unceremoniously left for another province and the case was left insoluble.

Case 7: During the same period, some members of the church levelled allegations of polygamy against a pastor. Following reports to the Provincial Overseer, investigations were made and the matter was deliberated at a Provincial Council meeting, which made a resolution to suspend the pastor indefinitely.

Case 8: Around the same period, there was a case that involved a wrangle over the control of an assembly between a deputy Overseer and a probationer (a pastor on trial after completing theological training). Tension flared up and turned ugly following a decision by the Provincial Committee to place the deputy Overseer at the assembly, whose resident pastor was a probationer. When pressure from the Provincial Committee mounted on the probationer to create space for the deputy Overseer, the matter became insoluble following the probationer's decision to unceremoniously leave AFM in Zimbabwe for another denomination.

Case 9: In 1997, some church members levelled allegations of attempted rape against a pastor. The pastor was arrested with subsequent trial in a court of law. The provincial council deliberated on the matter and the Apostolic Council suspended the pastor without benefits while awaiting placement under censure. The matter came to a standstill following the untimely death of the alleged pastor.

Case 10: In 1999, some members of the Provincial Committee levelled allegations of embezzling church funds against a Provincial Overseer. The Provincial Committee made investigations, which prompted discussions in the Provincial Council and the matter was referred to the Apostolic Council that did not resolve the case promptly. This development bred factionalism, which rocked the assembly under the jurisdiction of the alleged Overseer. Consequently, the two factions waged bitter war to gain control over the affairs of the congregation in which some youths resorted to physical force during the period 2001 to 2003 to ensure their favoured pastor retains control. The Zimbabwe Republic Police had to be called in to restore order. In 2003, the alleged Overseer was arrested with subsequent trial in a court of law but was acquitted without pleading guilty (Masvingo Star Newspaper 2003:5; The Daily News 2003). In an attempt to break the impasse, in 2004, an extraordinary joint meeting involving the Apostolic Council and Masvingo Provincial Committee was convened to discuss the matter. A decision to reinstate the Overseer against whom the allegations had been made came to a standstill as the Apostolic Council and Masvingo provincial council remained divided on whether to reinstate or ostracise the pastor. The matter died a natural death in 2005 when the Overseer was reinstated into ministry at another local church as an ordinary pastor.

Case 11: In year 2000, some elders levelled allegations of an extra-marital affair, resulting in a subsequent divorce against a pastor. The Provincial Committee referred the matter to the Apostolic Council ruling that investigated the matter and the pastor was ex-communicated.

Case 12: During the same period, some elders levelled allegations against a pastor for contravening church Constitution and Regulations in running church business. The Provincial Committee resolved the matter by appointing a new local board of elders and admonished the pastor to work hand in glove with church elders as prescribed by the constitution.

Case 13: In 2005, some elders levelled allegations of drunkenness against a pastor. Because the matter remained insoluble, it spilled over to 2007.

However, as the foregoing acts of misconduct related by informants date back several years, this study has supplemented these incidents by capturing recent acts of misconduct by pastors in the AFM in Zimbabwe to give an up-to-date account of pastoral misconduct. In doing so, I analysed some sources with more up-to-date data.

Judging from search results found via the Google search engine, concerns pertaining to the behaviour of male pastors are still being reported through both electronic and printed media across provinces of the AFM in Zimbabwe. For 
example, members of one assembly in Harare waged a bitter war against the Provincial Overseer based on allegations of a unilateral decision to transfer their favoured pastor. In the same report, police reportedly rescued the detained Overseer from angry church members (Bulawayo 24 News 2013) and the matter came to a standstill.

In another report, about eight pastors who teamed up with some elders and deacons sued the current president (2015 to 2018) of the AFM in Zimbabwe together with his executive committee based on allegations of rigging church elections in 2015 (Newsday 2015; The Herald 2015; Zimeye Newspaper 2015a; 2015b). In addition, Mhlanga (2016) reported that a pastor in Chitungwiza was suspended from performing pastoral duties and his assembly was closed on allegations of conspiracy and misappropriation of church funds. In another report, a pastor in Ruwa district was arrested on allegations of raping a congregant (New Zimbabwe 2016a; The Herald 2016a; 2016c). Another pastor is also reported to have appeared in court for allegedly raping four married women (ZimMetro News 2015). Similarly, in Bulawayo, a pastor reportedly raped a minor aged 16 years after he had offered her a lift after a church service (Chronicles 2017). Although the foregoing cases of pastoral misconduct are not exhaustive, they however confirm what is happening in the church under review not only in Masvingo province but also across Zimbabwe.

\section{Discussion of the results}

In the current study, disciplinary action against pastors who have committed acts of misconduct is a very strong theme. The church derives its strength from the Constitution and Regulations and from the Policy Document. Chapter 16 of the Constitution and Regulations states that:

The aim of discipline is either to stop or remove the corruption of sin from the ranks of the church and to help the transgressor by disciplinary measures to regain the right relationship with God and the church. (Chapter 16, 1.2)

It is the Constitution and Regulations and the CCGHP that seem to reflect and shape the general mood of almost every member of the AFM in Zimbabwe in terms of how pastoral misconduct is addressed. By coming up with a CCGHP, the $\mathrm{AFM}$ in Zimbabwe indicates acknowledgement that misconduct is a challenge that requires the attention of the church. In fact, AFM in Zimbabwe church members are committed to putting the offender under censure because, historically, the denomination has held disciplinary action against offending pastors as a central component of its mission. The CCGHP supports the church's stance on disciplinary action. It states that 'the basis of all discipline is to maintain the glory of God and to promote the welfare of the church' (Chapter 14.1.2).

As evidence from this study indicates, the behaviour of pastors is a major hindrance to the church's appropriation of one voice because when acts of misconduct are committed, usually there are negative feelings that go along with them.
Simply put, the behaviours of pastors are viewed as social ills that always negates development and a source of all distressed relationships that militate against sustaining harmony in the entire church (Chivasa 2012:1). Although the church still responds with punitive disciplinary measures to curb pastoral misconduct, more still needs to be done to improve the relationships between offending pastors and the church.

Chivasa and Machingura (in press) highlighted that if a pastor is involved, for instance, in misappropriation of church funds, an extra-marital affair or any other misdemeanour, the church will not grow either numerically or spiritually. If anything, such situations create disgruntlement, and tear the church apart. Spiritually and morally, pastoral misconduct stains the purity of the church. To the wider community, people who might want to convert to Christianity may get discouraged now that the leaders from whom they seek spiritual guidance are involved in such vices. Put differently, when a pastor commits an act of misconduct, there are a number of social and spiritual concerns that arise, many of which create dilemmas for the church resulting in discordance. Thus, pastoral misconduct drains a lot of social and spiritual energy from the church at large (Chivasa 2012:2), and this state of affairs calls for a relationship-oriented framework to help repair broken relationships in the process of addressing an act of misconduct.

In fact, in a significant portion of the time and effort of the AFM in Zimbabwe as a whole over the past 20 years, the church has mainly addressed conflict through disciplinary action (AFM Constitution and Regulations, Chapter 16). Put differently, the AFM in Zimbabwe is well known for its absolute stance on putting offenders under censure, which ranges from 3 to 12 months. In worst-case scenarios, a pastor who commits misconduct can be ostracised and the church takes pride in taking such disciplinary measures.

In fact, disciplinary action has gone a long way towards extenuating, though perhaps reflexively, the effects of pastoral misconduct on church members at large, but disciplinary action has not helped to improve the relationships, friendships and trust in the church (Chivasa and Machingura in press). Chivasa (2012:70) observed that disciplinary action against offenders seems to be a natural outgrowth of Christian work and he suggested that with proper training in conflict resolution, each local church and province of the AFM in Zimbabwe could become a strong force for constructive dialogue. For the AFM in Zimbabwe, disciplinary action against offenders is seen as service to God because it helps to promote virtuous Christian living. For that reason, the AFM in Zimbabwe is generally wary of swapping doctrinal purity with compromises a tendency the church generally sees in many emerging ministries in Zimbabwe in which some men of the cloth continue to preach in spite of allegations of promiscuity levelled against them (New Zimbabwe 2016b; The Herald 2016a; 2016b). Nevertheless, a relationship-oriented framework is crucial bearing in mind that Christianity is a relationship-oriented religion. 


\section{Implications for peace building}

As evidence suggests, a framework with the propensity to build positive working relationships in the AFM in Zimbabwe is inevitable. Gravingholt, Ganzle and Ziaja (2009:9) point out that discordance provides the context for peace building in that peace building seeks to enhance and restore existing social ties, trust, friendliness and bonds between individuals and groups (Fred-Mensah 2004; Schirch 2004:18). This process of enhancing and restoring relationships is the basis of peace building. Thus, peace building does not seek to eliminate discordance but to work out solutions to a discordant situation, which does not harm people's relationships, friendships, social networks and trust. It is a known fact that Christians subscribe to values such as love, compassion, faithfulness, peacefulness, tolerance and forgiveness, all of which are central to peace building. These values can serve as the entry point into a peace building framework.

Accordingly, introducing a peace building framework in the AFM in Zimbabwe should not be viewed as a compromise of the doctrine of purity, which primarily emphasises good working relations between people. Overseers, pastors and elders who are so inclined to the purity doctrine would surely remain key stakeholders in which case their primary responsibility should be to build relationships, trust and friendship between offending pastors and the church. Ideally, one of the comparative advantages that AFM in Zimbabwe peace building efforts would have is that local church groups at the community level, district structures, provincial and national structures are already in place and they need to be effectively utilised.

The best way to start is to create a peace building task force that is a structure at the local church level comprising pastors, elders, deacons and ordinary church members. I have realised that churches work best with structures. Because almost every church structure comprises seven members, a committee of seven can be retained when creating a structure for peace building. Chivasa (2012:70) proposed that a conflict resolution training centre for the AFM in Zimbabwe is a worthwhile investment. In the same report, he emphasised that the centre should aim to train members of the church in peer mediation skills. It is out of this peer mediation training that the church can infuse the acquired skills to address emerging conflict. As such, the creation of a peace building task force will positively help the church at large to treat offenders as parties to a discordance with an obligation to tell their story and to be listened to seriously before making a unilateral decision to put an offender under censure. In other words, the unavailability of a peace building task force in local churches of the AFM in Zimbabwe impoverishes the highly prized work of forgiveness, reconstruction, restoration and reconciliation (https://www.facebook.com/permalink. php?story_fbid...id) preached by the current Archbishop (president) of the AFM in Zimbabwe ever since 2003 when he assumed office.
Nevertheless, the encouraging thing about AFM in Zimbabwe is that it comprises church members who are conversant with values that cut across Christianity and peace building. These values include love, compassion, kindness, justice, reconciliation and forgiveness to mention but a few. More so as a denomination, the AFM in Zimbabwe demands that its members be committed to forgiveness, reconciliation, compassion, mercy, fair play, the love of neighbours and kindness. These values can serve as normative motivations for the creation of a peace building task force at every level of the local church, district, province and at the national level given that Christians are commanded to be 'peacemakers' (Matthew 5:9). Peacemaking is one of the values of godliness as well as that of peace building and this value is important for the AFM in Zimbabwe because in all its efforts it is on the path to pursuing godliness.

\section{Conclusion}

The main purpose of this study is to report acts of misconduct by male pastors and how they are being handled in the AFM in Zimbabwe church. Specifically, the study was aimed at investigating whether the church under review has any policy framework designed to repair distressed relationships between the offending pastors and the church. Results have shown that once a male pastor has committed misconduct, he is placed under censure. The church takes no further action to address issues of the relationship between the offending pastor and the very church where an act of misconduct occurred. The negative impact of pastoral misconduct on relationships is still a blind spot in the procedures for handling misconduct. Against such circumstances, a peace building framework would help to promote relationships given that enhancing and restoring relationships is at the heart of peace building.

A peace building framework was found to be appropriate because its values are compatible with Christianity. The AFM in Zimbabwe demands that its members be committed to forgiveness, reconciliation, compassion, mercy, fair play, the love of neighbours and kindness and these values are central to peace building. A peace building task force as suggested can be created at the local church level right up to national levels. The encouraging thing is that the Christian Bible commends that individuals should be peacemakers (Matthew 5:9). Building relationships is one way of practicing peacemaking. Because the AFM in Zimbabwe comprises groups of people who interact regularly, misconduct is unavoidable. Under such circumstances, a peace building framework is imperative as it will help to build and strengthen the relationships not only with offending pastors but the entire church as well. In the follow-up article, I examined the causes of and interventional solutions to pastors' moral failures in the AFM in Zimbabwe. An understanding of the causes of pastors' moral failures is a prerequisite for a sustainable peace building framework in the AFM in Zimbabwe church. 


\section{Acknowledgements}

A special thanks goes to the AFM in Zimbabwe church President for allowing me to conduct this research. I also convey my deepest gratitude to Carol Brammage for copyediting the draft manuscript.

\section{Competing interests}

The author declares that he has no financial or personal relationships which may have inappropriately influenced him in writing this article.

\section{References}

Apostolic Faith Mission in Zimbabwe, viewed 27 January 2017, from http://www. pindula.co.zw/Apostolic_Faith_Mission_in_Zimbabwe

Barna Group, 2016, 'Here's how 770 pastors describe their struggle with porno', Christianity Today, 26 January, viewed 31 January 2017, from http://www. christianitytoday.com/gleanings/2016/january/how-pastors-struggle-pornphenomenon-josh-mcdowell-barna.html

Bulawayo 24 News, 2013, 'AFM church overseer accused of being used by the devil', 16 January, viewed 31 January 2017, from http://bulawayo24.com/index-idnews-sc-religion-byo-25048.html

Cecil, T.R., 1997, 'Sexual failures among spiritual leaders', PhD theses submitted for the degree of Doctor of Ministry, Acadia University, Canada.

Chivasa, N., 2012, The nature, causes and consequences of conflicts involving pastors, LAP Lambert Academic Publishing, Saarbrucken.

Chivasa, N. \& Machingura, F., in press, 'One person's meat is another's poison: Conflic management and resolution in the Apostolic Faith Mission in Zimbabwe.'

Chronicles, 2017, 'AFM pastor rapes 16-year-old congregant after church service', 4 January, viewed 30 January 2017, from http://www.chronicle.co.zw/afmpastor-up-for-rape-of-congregant-16/

Constitution \& Regulations of the Apostolic Faith Mission in Zimbabwe church, Harare.

Criminal Law (Codification and Reform) ACT [Chapter 9: 23], viewed 21 March 2017 from http://www.ilo.org/dyn/natlex/docs/ELECTRONIC/72803/74195/F8588998 12/ZWE72803.pdf

Dr. A and Amai Madziyire's inspirational page, viewed 30 January 2017, from https:// www.facebook.com/permalink.php?story_fbid...id

Fred-Mensah, B.K., 2004, 'Social capital building as capacity for post-conflict development: The UNDP in Mozambique and Rwanda', Global Governance 10, 473-457.

Gravingholt, J., Ganzle, S. \& Ziaja, S., 2009, Policy brief: Concepts of peacebuilding and state building-how compatible are they? Germany Development Institute.

Hwata, B., 2005, 'An investigation of different phases of pentecostal experience in the Apostolic Faith Mission (AFM)', Maters Dissertation submitted to University of South Africa, Pretoria.

Johnson, J., 2015, 'The causes and cure of the moral failure of pastors', viewed 30 January 2017, from http://jerryjohnston.com/wp-content/uploads/2015/07/ JJ-Chapter3.pdf

King, W., 1988, 'Swaggart says he has sinned; will step down', The New York Times, 22 February, p. 1.

Machingura, F., 2011, 'The significance of glossolalia in the Apostolic Faith Mission, Zimbabwe', Studies in World Christianity 17(1), 12-29. https://doi.org/10.3366/ swc.2011.0003

Madziyire, A. \& Risinamhodzi, T., 2015, Pentecostal dawn in Zimbabwe: The history and Tenets of AFM, The Brand Guy and Associates, Harare.

Malaty, T.Y., 1992, Dictionary of church terms, St. George's Coptic Orthodox church, Alexandria, Egypt.
Masvingo Star, 2003, 'Divisions rock Apostolic Faith Mission in Zimbabwe', Masvingo, 7-13 February, p. 5.

Mhlanga, B., 2016, 'AFM fires senior pastor, closes assembly', The Standard, January 3, viewed 31 January 2017, from https://www.thestandard.co.zw/2016/01/03/afmfires-senior-pastor-closes-assembly/

Moyo, H., 2015, 'Pastoral care in the healing of moral injury: A case of the Zimbabwe National Liberation War Veterans', HTS Teologiese Studies/Theological Studies 71(2), 1-11. https://doi.org/10.4102/hts.v71i2.2919

Murefu, T.I., 2015, Let the fire of God fall again. A history of the Apostolic Faith Mission in Zimbabwe, A Centennial Edition 1915-2015, Harare.

Newsday, 2015, 'Fierce leadership row rock AFM', 14 April, viewed 30 January 2017 from https://www.newsday.co.zw/2015/04/14/fierce-leadership-row-rocks-afm/

New Zimbabwe, 2016a, 'Top Harare pastor Makomo rapes follower, blames the devil', 26 August, viewed 30 January 2017, from http://www.newzimbabwe.com/news30908

New Zimbabwe, 2016b, 'Zimbabwe: Magaya rape accuser withdraws case, says threatened with death', 15 November, viewed 01 February 2017, from http:// allafrica.com/stories/201611160080.html

Nhumburudzi, L., 2016, 'Leadership succession in Zimbabwe's Pentecostal churches: The case study of the Zimbabwe Assemblies of God Africa (ZAOGA) and The Apostolic faith mission in Zimbabwe (AFM)', A master's dissertation submitted to Bindura University of Science Education, Bindura, Zimbabwe.

Policy Document of the Apostolic Faith Mission in Zimbabwe church, Harare.

Robert, G.H.M., Robert, S.C., Robert, H.M., III, Evans, W.J., Honemann, D.H., Balch, T.J. et al., 2011, Robert's rules of order: Newly revised, 11th edn., Da Capo Press, Philadelphia, PA.

Rowdon, H., 2009, Church leader's handbook, Paternoster, London.

Roys, J., 2015, 'Your husband's infidelity not your fault', Christianity Today, viewed 31 January 2017, from http://www.christianitytoday.com/women/2015/october/ your-husbands-infidelity-is-not-your-fault.htm

Schirch, L., 2004, 'Strategic peacebuilding: State of the field', South Asian Journal of Peacebuilding 1(1), 1-17.

Smietana, B., 2016, 'Few pastors say adultery should permanently ban them from pulpit', Christianity Today, 10 May, viewed 30 January 2017, from http://www. christianitytoday.com/gleanings/2016/may/few-pastors-say-adultery-shouldpermanently-ban-pulpit.html

Taylor, J., 2004, 'Doctrine of the church (ecclesiology)', viewed 20 March 2017, from https://www.agts.edu/faculty/faculty_publications/class\%20notes/taylor_jay/ taylorj_7doct_church_2004.pdf

The Daily News, 2003, 'Zimbabwe: Pastor faces theft charges', 4 February, viewed on 31 January 2017, from http://allafrica.com/stories/200302040223.html

The Herald, 2015, 'Disgruntled members sue AFM executive', 14 April, viewed 31 January 2017, from http://www.herald.co.zw/disgruntled-members-sue-afmexecutive/

The Herald, 2016a, 'Zimbabwe: Magaya demands trial date', 28 September, viewed 01 February 2017, from http://allafrica.com/stories/201609281015.html

The Herald, 2016b, 'Zimbabwe: I was never raped-Magaya accuser', 2 December viewed 01 February 2017, from http://allafrica.com/stories/201612020340.html

The Herald, 2016c, 'AFM pastor's rape case crumbles', 15 December, viewed 31 January 2017, from http://www.herald.co.zw/afm-pastors-rape-case-crumbles/

The Special Education Dictionary, 2003, 'Misconduct', viewed on 16 March 2017, from https://www.google.co.za/?gfe rd=cr\&ei=hMbKWMf_G4yp8weJgbKQDg\#q=Spe cial+Education+Dictionary,+2003+-misconduct $\& *$

Tillett, G., 1999, Resolving conflict: A practical approach, Oxford University Press, Oxford.

Togarasei, L., 2016, 'Historicising Pentecostal Christianity in Zimbabwe', Studia Historiae Ecclesiasticae 1-13.

Zimeye Newspaper, 2015a, 'AFM church in dirty election rigging: Court papers', 13 April, viewed 30 January 2017, from http://www.zimeye.net/afm-pastors-contestchurchs-president-election/

Zimeye Newspaper, 2015b, 'AFM church hires NIKUV to rig pastors' elections!members', 14 April, viewed 31 January 2017, from http://www.zimeye.net/nikuvelections-rip-afm-church-apart-members/

ZimMetro News, 2015, 'AFM pastor rapes four married women', 14 October, viewed 30 January 2017, from http://zimetro.com/afm-pastor-rapes-four/ 